\title{
Performance of mulberry cultivars (Morus spp.) in response to different stem cuttings and fertilizers
}

Anelisa de Aquino Vidal Lacerda Soares ${ }^{1}$, Fernanda de Paiva Badiz Furlaneto ${ }^{2}$, Cláudio Hajime Funai ${ }^{3}$, Eduardo Gazola ${ }^{3}$

\author{
${ }^{1}$ Agência Paulista de Tecnologia dos Agronegócios - APTA Polo Centro Oeste, Bauru, SP. ${ }^{2}$ Agência Paulista de \\ Tecnologia dos Agronegócios - APTA UPD Marília, Marília, SP. ${ }^{3}$ Núcleo de Produção de Mudas de Marília, CATI CDRS, \\ Marília, SP. E-mail: vidal@apta.sp.gov.br
}

\begin{abstract}
The objective is to analyze techniques to form mulberry seedlings with different cutting sizes and forms of fertilization with N-P-K aiming a low production cost and an easy application in field. The experiment was carried out in a screened nursery, with a shading of $34 \%$. The treatments were distributed in randomized blocks (RB) and compared in a $2 \times 4 \times 3$ factorial design with five replications and 12 plants per plot. The factorial design consisted of two cutting lengths $(10$ and $20 \mathrm{~cm})$ distributed in plastic tubes of 70 and 120 $\mathrm{mL}$, four mulberry cultivars (IZ40, IZ10/1, Korin, and IZ3/2), and two types of fertilization: addition of $84 \mathrm{~g}$ of Osmocote ${ }^{\circledR}$ for each kilo of substrate, fertigation with aqueous solution containing $84 \mathrm{~g}$ of 14-14-14 N-P-K for each kilo of substrate, plus a control treatment (without fertilization). The commercial substrate Basaplant citrus ${ }^{\circledR}$ was used. 90 and 140 days after planting, assessments of percentage of rooting were carried out. At 140 days, shoot length $(\mathrm{cm})$, number of shoots, number of leaves, root length $(\mathrm{cm})$, and shoot and root green and dry matter were evaluated. The data obtained were evaluated using the Sanest software and Tukey test $(P<0.05)$. Cuttings of $20 \mathrm{~cm}$ in length in tubes of $120 \mathrm{~mL}$ are recommended for the best formation of mulberry seedlings with the application of N-P-K fertilizer through fertigation. The cultivars showed different rooting potentials and shoot development. The best results are for Korin and IZ $10 / 1$.
\end{abstract}

Keywords: mulberry; rooting; woody cuttings; seedling production; vegetative propagation.

\section{Formação de mudas de amoreira (Morus spp.) em diferentes tamanhos de estacas e de adubação}

\section{Resumo}

Objetivou-se estudar técnicas de formação de mudas de amoreira com diferentes tamanhos de estacas e formas de adubação com NPK visando baixo custo de produção e fácil aplicação no campo. O experimento foi realizado em viveiro do tipo telado, com sombreamento de $34 \%$. Os tratamentos, distribuídos em um delineamento experimental de blocos ao acaso (DBC) foram comparados, em esquema fatorial do tipo $2 \times 4 \times 3$ com 5 repetições e 12 plantas por parcela, a saber: dois comprimentos de estacas, 10 e $20 \mathrm{~cm}$, distribuídas em tubetes plásticos de 70 e $120 \mathrm{~mL}$, quatro cultivares de amoreira (IZ40, IZ10/1, Korin e IZ3/2) e dois tipos de adubação: adição de $84 \mathrm{~g}$ de Osmocote ${ }^{\circledR}$ para cada quilo de substrato; fertirrigação com solução aquosa contendo 84g de NPK na formulação 14-14-14 para cada quilo de substrato e acrescido de um tratamento testemunha (sem adubação). Utilizou-se o substrato comercial Basaplant citrus ${ }^{\circledR}$. Aos $90 \mathrm{e}$ 140 dias após o plantio foram realizadas as avaliações da porcentagem de pegamento das estacas. Aos 140 dias, também, foram feitas avaliações do comprimento da parte aérea $(\mathrm{cm})$, número de brotações, número de folhas, comprimento da raiz $(\mathrm{cm})$, massas verde e seca da parte aérea e da raiz. Os dados obtidos foram avaliados por meio do programa Sanest e Teste de Tukey $(P<0,05)$. Concluiu-se que para a melhor formação das mudas de amoreira são recomendadas estacas de $20 \mathrm{~cm}$ de comprimento em tubetes de $120 \mathrm{~mL}$ com a aplicação do adubo NPK através da fertirrigação. As cultivares apresentaram diferentes potenciais de enraizamento e desenvolvimento da parte aérea sendo os melhores resultados encontrados para a Korin e IZ 10/1.

Palavras-chave: amora; enraizamento; estacas lenhosas; produção de mudas; propagação vegetativa. 


\section{Introduction}

Mulberry, a plant belonging to the family Moraceae and the genus Morus, traditionally used to feed silkworm caterpillars (Bombyx mori L.), produces fruits made up of phenolic compounds that have several properties, such as antioxidant and antimutagenic actions (HAIDA et al., 2014). This crop has low production costs and requires little use of pesticides, making it an option for organic cultivation (ZENI et al., 2017; PADILHA et al., 2010).

Research related to seedling propagation methods is essential for professionals who own commercial nurseries and work with genetic improvement, as well as for rural entrepreneurs and processing industries, because it guides the formation of uniform and quality plantings. However, studies on mulberry (Morus sp.) are still scarce, especially regarding cutting length (YAMAMOTO et al., 2013; BRANDÃO et al., 2020).

The production of seedlings in tubes preserves the integrity of the root system in the nursery and improves the working conditions of workers (tubes suspended from the ground) (LIMA, 1986; VICHIATO, 1996), thus facilitating handling inside the nursery, transportation, and planting (CAMPINHOS JÚNIOR et al., 1983). In addition, the use of tubes shortens the nursery period, anticipates planting in field, minimizes usage of substrate, avoids weeds, eliminates substrate purging, and eliminates root entanglement during the nursery phase, which continues in the field phase and may decrease the stability of future trees (GUIMARÃES et al., 1998; BARBIZAN et al., 2002).

Several studies on different species have shown, for forest restoration and for production of fruit plant seedlings, that large containers usually provide a better quality to seedlings (BOMFIM et al., 2009). However, associating fertilization that meets the needs of seedlings using small containers may reduce costs in production, transport, and distribution in field, leading to the formation of high-quality seedlings, lower costs, and better yield in the planting operation, which decrease the costs of implanting an orchard (LIMA FILHO et al., 2019; HAWERROTH et al., 2013).

Modern fruit growing excels in obtaining high-quality seedlings. In this sense, fertilization with nutrients is essential to produce seedlings in nurseries aiming a rapid growth with vigorous, resistant, and rustic characteristics. Only thus can seedlings withstand the most varied conditions after planting in the field (GONÇALVES; BENEDETTI, 2005; BRUGNARA, 2018).

Primary macronutrients ( $\mathrm{N}, \mathrm{P}$, and $\mathrm{K}$ ) are usually added to the substrate in solid form, but they can also be supplied as a liquid (fertigation) (LANDIS et al., 1989). The production of seedlings in tubes is a promising technique but still little investigated. It is necessary to verify its technical and economic viability. On the other hand, part of the substrates used for the production of seedlings do not contain all essential nutrients in adequate amounts for the growth and development of plants, which makes fertilization a necessary agronomic practice to obtain seedlings with an excellent quality. In addition, the frequent irrigation required for the production of seedlings considerably increases loss of nutrients by leaching, which requires replenishment in installments by leaf spraying or covering, or by fertigation (TEIXEIRA et al., 2009). Usually, supplementing the substrate with nutrients for seedlings in tubes is usually done using slow-release fertilizers, such as Osmocote ${ }^{\circledR}$, in order to reduce problems of excess solubility and losses due to nutrient leaching (BARBIZAN et al., 2002; ALMEIDA et al., 2019).

Given the above, the objective is to analyze techniques to form mulberry seedlings with different cutting sizes and forms of fertilization with N-P-K aiming a low production cost and an easy application to obtain vigorous and uniform seedlings in field.

\section{Materials and Methods}

The experiment was carried out in a screened nursery with $34 \%$ shading and benches suitable for tubes located at the Seedling and Seed Production Center of the Secretariat of Agriculture and Supply of the State of São Paulo, municipality of Marília, SP, Brazil.

The installation of the experiment consisted of preparing and filling tubes with the commercial substrate Basaplant citrus ${ }^{\circledR}$, planting by stem cutting, burying about two thirds of the length inside soil, and following this experimental design: randomized blocks (RB) with five replications. The treatments were in a $2 \times 4 \times 3$ factorial design with 12 replications, namely: two cutting lengths $(10$ and $20 \mathrm{~cm})$, distributed in plastic tubes of 70 and $120 \mathrm{ml}$ suitable for the production of eucalyptus and coffee seedlings, respectively; four mulberry cultivars: IZ40, IZ10/1, 
Korin, and IZ3/2; and two forms of fertilization: addition of $84 \mathrm{~g}$ of Osmocote ${ }^{\circledR}$ for each kilo of substrate, fertigation by applying an aqueous solution containing $84 \mathrm{~g}$ of 14-14-14 N-P-K for each kilo of substrate, plus a control treatment (without fertilization).

The stem cuttings of the four mulberry cultivars, from adult plants and healthy branches, with an average diameter between 1.0 to $1.5 \mathrm{~cm}$, were harvested in field the day before planting. The branches were cut in two lengths taking into account the treatments proposed in this study. All cutting units, regardless of size, were collected with two leaves of an equivalent size. In all treatments, sprinkler irrigation was performed daily in a sufficient volume to maintain the substrate moisture.

The application of fertilizer was carried out weekly using an aqueous solution distributed in each tube using a graduated cylinder. In each tube, $5 \mathrm{~mL}$ of solution containing N-P-K were applied in a formulation 14-14-14, beginning 40 days after growth and the beginning of sprout development.

In evaluations, the rooting index was determined after 88 days of planting by the percentage of cuttings with leaves. After 140 days, sprouts were studied by measuring seedling height using a graduated ruler taking as a reference the distance from the neck to the apex of the plant (apical meristem). Then, the seedlings were removed from the tubes; the roots were washed and placed on absorbent paper to remove excess moisture; and then the main root length $(\mathrm{cm})$ and the total mass $(\mathrm{g})$ were evaluated.

The analyses of fresh and dry matter (in grams) of shoots and the root system were carried out in the laboratory of the Research and Development Unit of Marília/APTA. To obtain dry mass, the fresh samples were weighed and then placed in an oven with forced air circulation at $65^{\circ} \mathrm{C}$ for 72 hours; after cooling in ambient conditions, they were weighed, thus determining the weight of dry mass.

The data obtained were evaluated using the Sanest software. When the $F$ value was significant, the treatment means were compared using the Tukey test $(\mathrm{P}<0.05)$.

\section{Results and Discussion}

88 days after planting, most stem cuttings survived (Figure 1) and showed more than $60 \%$ of rooting index, mainly for cuttings with a length of $20 \mathrm{~cm}$ (Figure 1B). In $10-\mathrm{cm}$ cuttings, fertilization with Osmocote ${ }^{\circledR}$ showed a better percentage of rooting in the cultivars Korin and IZ10/1 (100\%), followed by the cultivars IZ40 and $1 Z 3 / 2$, with rates of $75 \%$ and $67 \%$, respectively (Figure $1 \mathrm{~A}$ ). For the $20-\mathrm{cm}$ cuttings, only the cultivar IZ40 reached $100 \%$ of rooting in all evaluated treatments (Figure 1B).

Okamoto et al. (2013) evaluated the cutting length and substrates in the production of mulberry seedlings and identified that cuttings with $20 \mathrm{~cm}$ in length had better rooting indexes compared to cuttings of $10 \mathrm{~cm}$ because the amount of reserves in the branch is proportional to the cutting size and this may contribute to the initial development of sprouting. However, this result is not directly related to the rooting of cuttings because the index is associated with other conditions represented mainly by the genetic potential (Okamoto et al., 2005; Okamoto et al., 2013).

At 140 days, there was a reduction in the rooting rates for all cultivars, both for lengths of 10 and $20 \mathrm{~cm}$, as well as for all treatments evaluated (Figure 2). Only the cultivars Korin and $\mathrm{IZ10} / 1$ in the treatment with Osmocote ${ }^{\circledR}$ maintained $100 \%$ of stem cuttings with leaves and roots (Figure $2 \mathrm{~A}$ ). For the $20-\mathrm{cm}$ length, only the cultivar IZ40 remained with a rooting index higher than $90 \%$ regardless of the treatment evaluated (Figure 2B). 
Figure 1. Percentage of rooting of mulberry cuttings with leaves (four cultivars), cut in two different lengths $\left(10\right.$ and $20 \mathrm{~cm}$ ), and fertilization (Osmocote ${ }^{\circledR}$, fertigation and without fertilization) 88 days after planting.

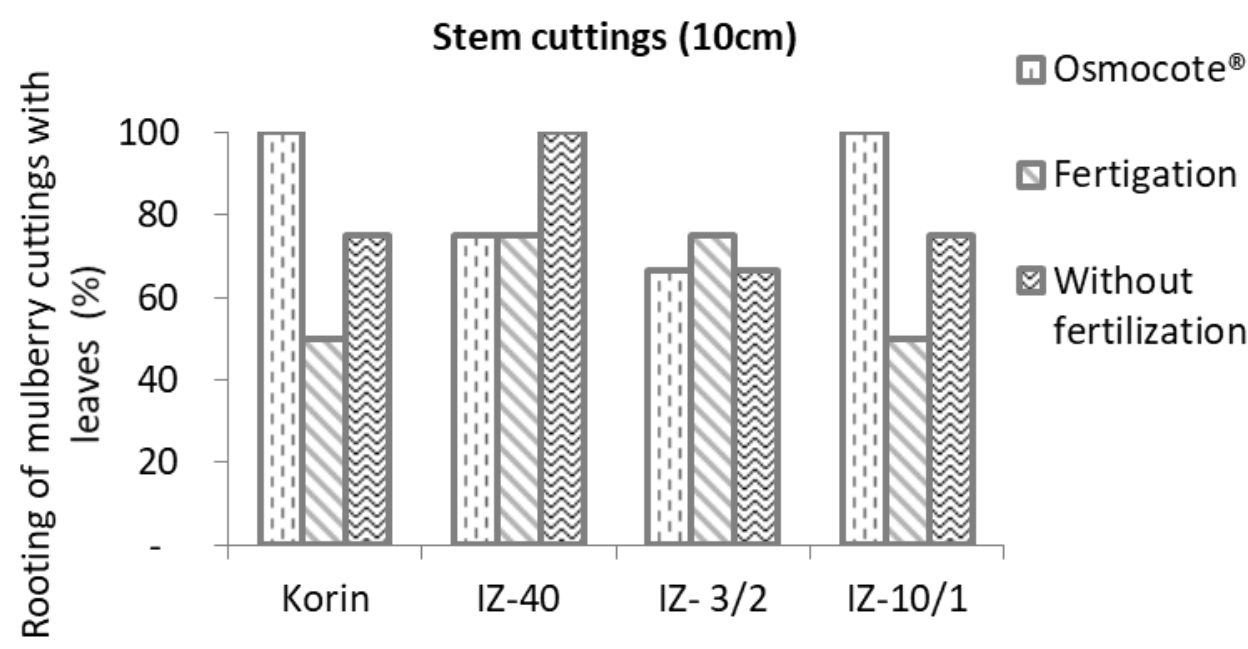

Mulberry of cultivars (Morus spp.)

(A)

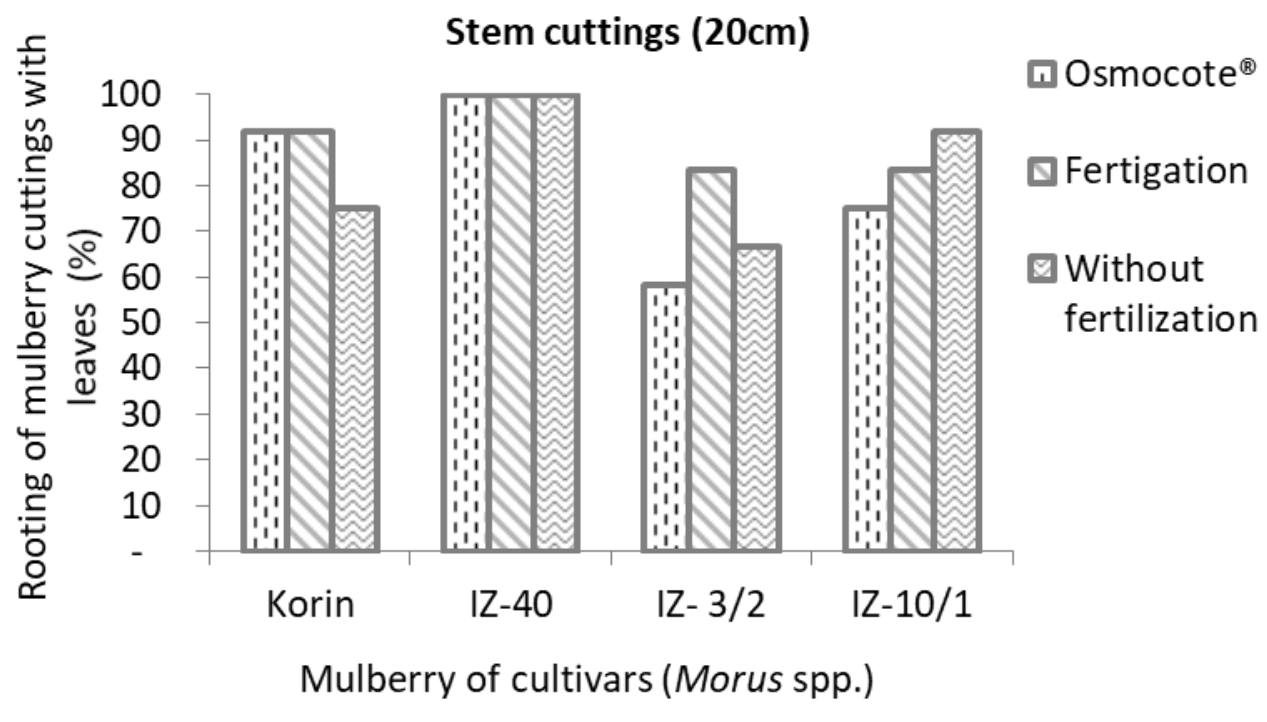

(B)
These results are in agreement with Teixeira et al. (2008) and Moreira et al. (2010). The authors, under controlled conditions with intermittent fogging, as is the case with seedling nurseries, reported that cuttings with 15 to $20 \mathrm{~cm}$ in length and a diameter between 4 and $10 \mathrm{~mm}$ showed good results of rooting in mulberries of the genus Morus.

In addition, in the cutting process, according to Villa et al. (2003), there are differences in the percentage of rooting between species and between cultivars. These differences can be attributed to internal conditions, such as hormonal reserves and genetic potential, in addition to external conditions, which justify the differences found between the cultivars evaluated in the present study (Figures 1 and 2). 
Figure 2. Percentage of rooting of mulberry cuttings with leaves (four cultivars), cut in two different lengths $\left(10\right.$ and $20 \mathrm{~cm}$ ), and fertilization (Osmocote ${ }^{\circledR}$, fertigation and without fertilization) 140 days after planting.

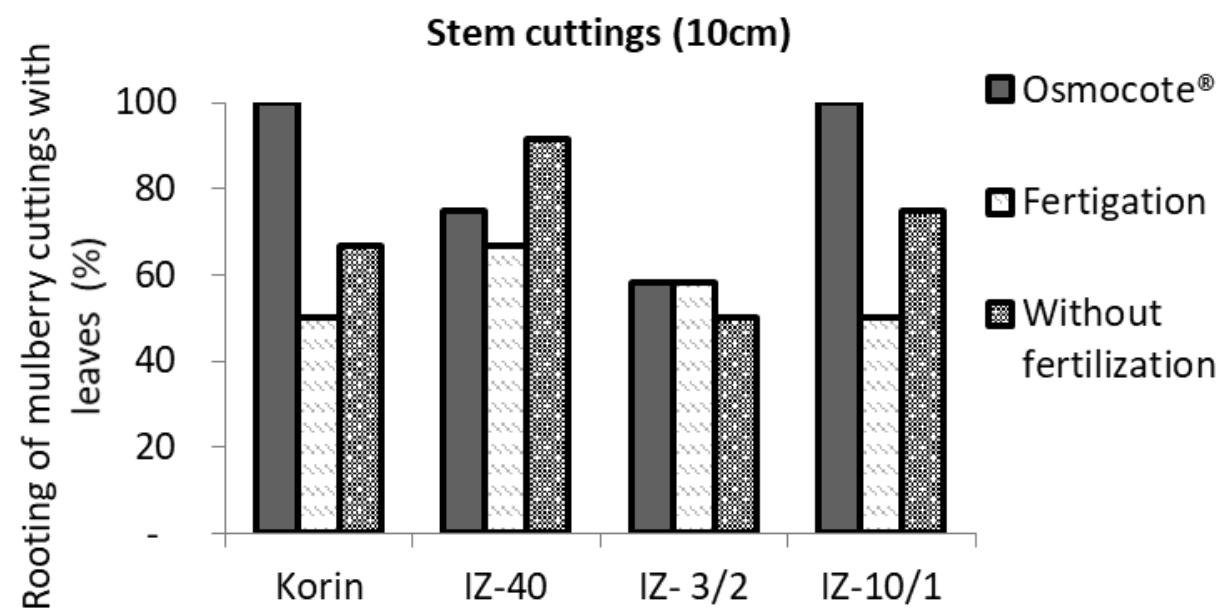

Mulberry of cultivars (Morus spp.)

(A)

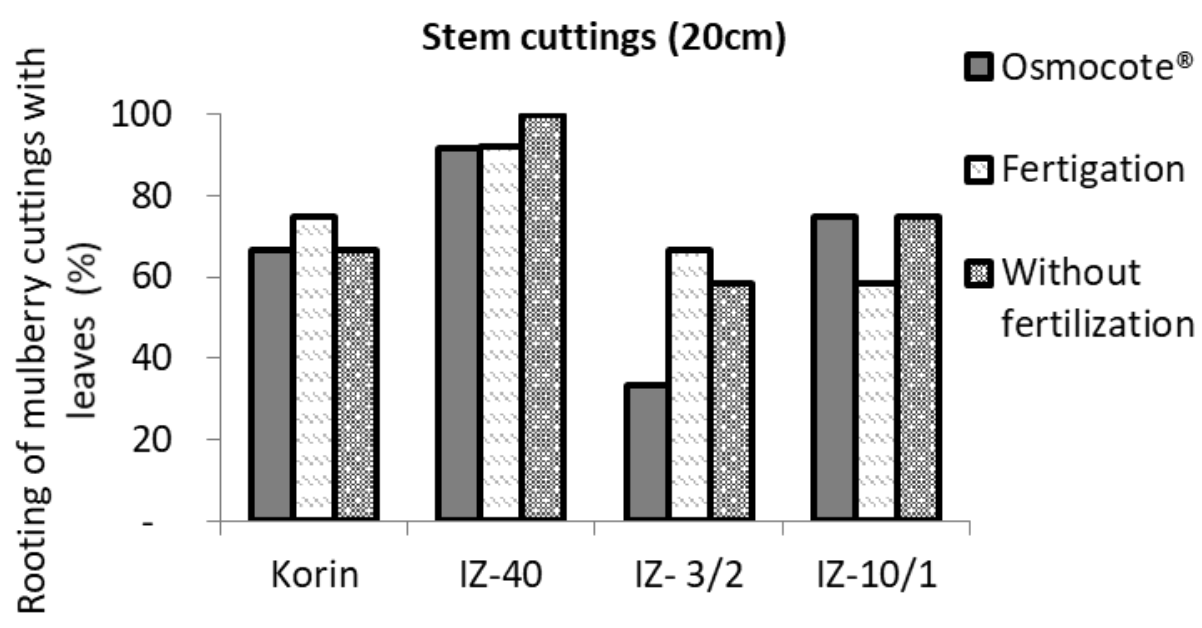

Mulberry of cultivars (Morus spp.)

(B)

The analysis of variance showed significant effects of cultivars (C), cutting length $(\mathrm{CL})$, and forms of fertilization (A) for most characteristics evaluated, except for root length of the studied cultivars; there were also effects of interactions for height, root length, shoot green and dry mass, and root green and dry mass, indicating that cutting length and forms of fertilization (Osmocote ${ }^{\circledR}$, fertigation with N-P-K and without fertilization) influenced the behavior of these characteristics of the cultivars along the formation of seedlings (Table 1). 
Table 1. Summary of analysis of variance (ANOVA) for height (A), root length (RL), shoot green mass (SGM), root green mass (RGM), shoot dry mass (SDM), and root dry mass (RDM) of mulberry cuttings.

\begin{tabular}{|c|c|c|c|c|c|c|c|}
\hline \multirow{2}{*}{$\begin{array}{ll}\text { Causes } & \text { of } \\
\text { variation } & \end{array}$} & & A & $\mathbf{R L}$ & SGM & RGM & SDM & RDM \\
\hline & DF & \multicolumn{6}{|c|}{ MS } \\
\hline Cultivars (C) & 3 & $\begin{array}{l}108.3966 * \\
*\end{array}$ & $9.2201^{\mathrm{ns}}$ & $8.5701^{* *}$ & * 11.4056* & $4.2832 * *$ & $0.5512 * *$ \\
\hline $\begin{array}{l}\text { Cutting length } \\
\text { (CL) }\end{array}$ & 1 & $93.6333^{* *}$ & $29.7008 * *$ & $44.3496 * *$ & * 22.3603* & * $16.6210 *$ & $1.1732 * *$ \\
\hline $\begin{array}{l}\text { Fertilization } \\
\text { (F) }\end{array}$ & 2 & $\begin{array}{l}160.1763 * \\
*\end{array}$ & $32.7933^{* *}$ & $9.5596 * *$ & $2.2397^{* *}$ & $2.0036 * *$ & $0.0567^{*}$ \\
\hline $\mathrm{C} \times \mathrm{CL}$ & 3 & $39.8691 * *$ & $47.3405^{* *}$ & $8.0532 * *$ & $3.5043^{* *}$ & $3.0251^{* *}$ & $0.1276^{* *}$ \\
\hline$C \times F$ & 6 & $25.1196 * *$ & $20.4626 * *$ & $2.7146 * *$ & $1.7049 * *$ & $0.4382^{* *}$ & $0.0563^{* *}$ \\
\hline$C L \times F$ & 2 & $9.8413^{\mathrm{ns}}$ & $10.3877^{\mathrm{ns}}$ & $0.365^{\mathrm{ns}}$ & $0.0324^{\mathrm{ns}}$ & $0.4068^{*}$ & $0.0575^{*}$ \\
\hline Treatment & 23 & 47.2177 & 22.8853 & 6.3876 & 3.8035 & 2.1449 & 0.1738 \\
\hline Residue & 69 & 6.4498 & 4.0611 & 0.7564 & 0.2272 & 0.0875 & 0.0168 \\
\hline CV (\%) & & 34.75 & 24.8256 & 34.16 & 29.4082 & 26.81 & 48.50 \\
\hline
\end{tabular}

$\mathrm{MS}=$ mean square; $\mathrm{DF}=$ degrees of freedom; $\mathrm{C} \times \mathrm{CL}=$ interaction between cultivars and cutting length; $\mathrm{C} \times \mathrm{F}=$ interaction between cultivars and types of fertilization; $\mathrm{CL} \times \mathrm{F}=$ interaction between cutting length and types of fertilization; CV $(\%)=$ coefficient of variation; ${ }^{* *}, *$ and $\mathrm{ns}$, significant at $1 \%$ and $5 \%$ probability and not significant, respectively.

Planting cutting lengths $(10$ and $20 \mathrm{~cm})$, as well as by the form of fertilization performed (Table 2), affected the sprouting heights of the cultivars studied. Regardless of cultivar, there was no difference between sprouting height in the cuttings of $10 \mathrm{~cm}$.

However, the cultivars IZ 40 and IZ 10/1 had the highest heights when the cut was $20 \mathrm{~cm}$, with values of 10.9 and $9.7 \mathrm{~cm}$, respectively. The sprouting of the cultivar $\mathrm{IZ} 3 / 2$ had the lowest height $(4.0 \mathrm{~cm})$ when formed by this same cutting size. Also, the fertilization with the solution containing N-P-K provided a greater plant height among the studied treatments, with the exception of the cultivar $\mathrm{IZ} 3 / 2$, which showed no differences between the forms of fertilization and the control treatment.

Unlike what Yamanishi et al. (2004) observed for papaya seedlings grown with two forms of fertilization (Osmocote ${ }^{\circledR}$ 14-14-14 and formulated 14-14-14 N-P-K) and three organic sources (humus, bovine manure, and Nutriplanta ${ }^{\circledR}$ ), in the present test the fertilization with N-P-K in aqueous solution stimulated a greater height of mulberry seedlings in comparison to the formulation of Osmocote ${ }^{\circledR} 14$ 14-14.

In relation to the average size of cuttings studied in the assay, the cultivar IZ 40 had a high height of sprouting. Among the means of cultivars, the $20-\mathrm{cm}$ long cuttings provided the highest heights.
Consistent with the sprouting height are the fresh and dry mass data, with no statistically significant differences between the cultivars studied and the $10-\mathrm{cm}$ cuttings (Table 2 ). The cultivar IZ $3 / 2$ obtained the lowest fresh and dry mass of sprout, resulting in values of 1.56 and $0.51 \mathrm{~g}$, respectively, for cuttings of $20 \mathrm{~cm}$. The means of fresh and dry masses were higher in the sprouts of cuttings of $20 \mathrm{~cm}$.

Considering that the amount of reserves in the branch is proportional to the cutting size, this may have contributed to a better initial development of sprouting in $20-\mathrm{cm}$ cuttings, which is in accordance with the technical recommendations of Tinoco et al. (2000) and Takahashi et al. (2009).

The form of fertilization was significantly different in the cultivars IZ10/1 and Korin for the production of green and dry mass, with emphasis on the application of fertilizer via fertigation compared to treatments with Osmocote ${ }^{\circledR}$ and without fertilization. Such data can be justified by the higher demand for nitrogen of the varieties $\mathrm{IZ10} / 1$ and Korin in comparison to the others, and the N-P-K formulation, which is soluble in water, makes this nutrient more readily available than Osmocote ${ }^{\circledR}$, which is a slow-release fertilizer.

Fonseca et al. (1973), who studied the deficiency of macronutrients and boron in three varieties of blackberry, observed that nitrogen deficiency symptoms were the first to appear and that the varieties Calabreza and Fernão Dias were 
more susceptible to nitrogen and phosphorus deficiency than the variety Formosa. Vale et al. (2009) studied the growth curve and the macronutrient absorption rate of three mulberry cultivars (FM Shima-Miura, IZ 56/4, and Miura) and found that nitrogen was at a greater concentration in all cultivars and that the phosphorus was extracted in small quantities, with accumulations of $0.26,0.46$, and $0.27 \mathrm{~g}$ of $\mathrm{P}$ per plant at 115 days after plant rootage.

The best development of the root system in $10 \mathrm{~cm}$ cuttings was in the cultivar $I Z 3 / 2$, which presented $8.8 \mathrm{~cm}$ in length, followed by the cultivar Korin and IZ40, with 7.8 and $7.4 \mathrm{~cm}$ in length, respectively (Table 3 ). However, this same behavior did not occur in $20-\mathrm{cm}$ stem cuttings. The cultivar IZ 3/2 had the shortest root length. On average, the cultivars showed a greater root length in cuttings of $20 \mathrm{~cm}$ compared to cuttings of $10 \mathrm{~cm}$.

Table 2. Unfolding of the interaction between cutting length $(C L)$ and forms of fertilization $(A)$ for the variables height $(\mathrm{cm})$ and fresh and dry mass $(\mathrm{g})$ of the sprouts of four mulberry cultivars.

\begin{tabular}{|c|c|c|c|c|c|}
\hline Parameter & IZ 40 & IZ 10/1 & Korin & IZ 3/2 & $\begin{array}{l}\text { Means of } \\
\text { cultivars }\end{array}$ \\
\hline \multicolumn{6}{|c|}{ Sprout height $(\mathrm{cm})$} \\
\hline C-10 & $7.3 \mathrm{bA}$ & $7.1 \mathrm{bA}$ & $5.7 \mathrm{bA}$ & $5.6 \mathrm{aA}$ & $6.4 \mathrm{~B}$ \\
\hline C-20 & 10.9 aA & $9.7 \mathrm{aAB}$ & $8.1 \mathrm{aB}$ & $4.0 \mathrm{aC}$ & $8.1 \mathrm{~A}$ \\
\hline \multicolumn{6}{|l|}{ MSD = 1.84} \\
\hline A1 & $7.5 \mathrm{bA}$ & $6.6 \mathrm{bAB}$ & $5.5 \mathrm{bAB}$ & $4.0 \mathrm{aB}$ & $5.9 \mathrm{~B}$ \\
\hline $\mathrm{A} 2$ & $11.8 \mathrm{aA}$ & $12.5 \mathrm{aAB}$ & $9.3 \mathrm{aB}$ & $4.7 \mathrm{aC}$ & $9.6 \mathrm{~A}$ \\
\hline A3 & $7.8 \mathrm{bA}$ & $6.0 \mathrm{bA}$ & $4.7 \mathrm{bC}$ & $5.6 \mathrm{aA}$ & $6.4 \mathrm{~B}$ \\
\hline \multicolumn{6}{|l|}{ MSD = 2.71} \\
\hline Means of factors & $9.1 \mathrm{a}$ & $8.4 a b$ & $6.9 \mathrm{~b}$ & $4.8 \mathrm{c}$ & \\
\hline \multicolumn{6}{|c|}{ Sprouting green mass (g) } \\
\hline C-10 & $2.01 b$ & $1.95 b$ & $1.57 b$ & $1.91 \mathrm{a}$ & $1.86 \mathrm{~B}$ \\
\hline$C-20$ & $3.80 \mathrm{aA}$ & $4.18 \mathrm{aA}$ & $3.35 \mathrm{aA}$ & $1.56 \mathrm{bB}$ & $3.22 \mathrm{~A}$ \\
\hline \multicolumn{6}{|l|}{$\mathrm{MSD}=0.71$} \\
\hline $\mathrm{A} 1$ & $2.46 a A$ & $2.72 \mathrm{bA}$ & $1.75 \mathrm{bA}$ & $1.66 \mathrm{aA}$ & $2.15 \mathrm{~B}$ \\
\hline $\mathrm{A} 2$ & $3.41 a A$ & 4.10 a $A$ & $3.66 \mathrm{aA}$ & $1.49 \mathrm{aB}$ & $3.16 \mathrm{~A}$ \\
\hline A3 & $2.84 a A$ & $2.38 \mathrm{bA}$ & $1.98 \mathrm{bA}$ & $2.04 \mathrm{aA}$ & $2.31 \mathrm{~B}$ \\
\hline \multicolumn{6}{|l|}{ MSD = 1.04} \\
\hline Means of factors & $2.91 \mathrm{a}$ & $3.06 \mathrm{a}$ & $2.46 \mathrm{a}$ & $1.73 \mathrm{~b}$ & \\
\hline \multicolumn{6}{|c|}{ Sprout dry mass (g) } \\
\hline C-10 & $0.79 b$ & $0.81 \mathrm{~b}$ & $0.63 \mathrm{~b}$ & $0.67 \mathrm{a}$ & $0.73 \mathrm{~B}$ \\
\hline$C-20$ & $2.10 \mathrm{aA}$ & $1.82 \mathrm{aA}$ & $1.46 \mathrm{aB}$ & $0.51 \mathrm{aC}$ & $1.47 \mathrm{~A}$ \\
\hline \multicolumn{6}{|l|}{$\mathrm{MSD}=0.21$} \\
\hline A1 & $1.26 \mathrm{bA}$ & $1.18 \mathrm{bA}$ & $0.74 \mathrm{bB}$ & $0.54 \mathrm{aB}$ & $0.94 \mathrm{~B}$ \\
\hline A2 & $1.79 \mathrm{aA}$ & $1.68 \mathrm{aA}$ & $1.45 \mathrm{aA}$ & $0.50 \mathrm{aB}$ & $1.35 \mathrm{~A}$ \\
\hline A3 & $1.28 \mathrm{bA}$ & $1.09 \mathrm{bAB}$ & $0.94 \mathrm{bBC}$ & $0.68 \mathrm{aC}$ & $1.00 \mathrm{~B}$ \\
\hline \multicolumn{6}{|l|}{ MSD = 0.31} \\
\hline Means of factors & $1.44 \mathrm{a}$ & $1.32 \mathrm{a}$ & $1.04 \mathrm{~b}$ & $0.59 c$ & \\
\hline
\end{tabular}

Means followed by the same lowercase letters in columns and uppercase letters in rows, if different, differ by Tukey test at $5 \%$ probability. C-10: $10 \mathrm{~cm}$ stem cuttings in $70 \mathrm{~mL}$ containers; C-20: $20 \mathrm{~cm}$ stem cuttings in 120 $\mathrm{mL}$ containers; A1: addition of $84 \mathrm{~g}$ of Osmocote ${ }^{\circledR}$ for each kilo of substrate; A2: fertigation with $84 \mathrm{~g}$ of 14-14$14 \mathrm{~N}-\mathrm{P}-\mathrm{K}$ formulation for each kilo of substrate; A3: without fertilization. 
There was a greater root green and dry mass in the cultivar IZ40 in both cuttings sizes (Table 3). Comparing the results of dry and green root mass means obtained for cutting length (10 and $20 \mathrm{~cm}$ ), there were higher values for the cuttings of $20 \mathrm{~cm}$.

Table 3. Unfolding of the interaction between cutting length $(C L)$ and forms of fertilization $(A)$ for the variables length $(\mathrm{cm})$ and root fresh and dry mass $(\mathrm{g})$ of four mulberry cultivars.

\begin{tabular}{|c|c|c|c|c|c|}
\hline Parameter & IZ 40 & IZ 10/1 & Korin & IZ 3/2 & $\begin{array}{c}\text { Means of } \\
\text { cultivars }\end{array}$ \\
\hline \multicolumn{6}{|c|}{ Root length $(\mathrm{cm})$} \\
\hline C-10 & $7.4 \mathrm{aAB}$ & $6.3 \mathrm{bB}$ & $7.8 \mathrm{bAB}$ & $8.8 \mathrm{aA}$ & $7.6 \mathrm{~B}$ \\
\hline $\mathrm{C}-20$ & $8.8 \mathrm{aA}$ & $9.5 \mathrm{aA}$ & $9.8 \mathrm{aA}$ & $6.2 \mathrm{bB}$ & $8.6 \mathrm{~A}$ \\
\hline \multicolumn{6}{|l|}{$\mathrm{MSD}=1.46$} \\
\hline A1 & $9.0 \mathrm{aA}$ & $8.1 \mathrm{aA}$ & $9.3 \mathrm{aA}$ & $8.6 \mathrm{aA}$ & $8.7 \mathrm{a}$ \\
\hline A2 & $7.8 \mathrm{aA}$ & $8.1 \mathrm{aA}$ & $9.0 \mathrm{aA}$ & $4.2 \mathrm{bB}$ & $7.07 \mathrm{~b}$ \\
\hline A3 & $7.6 \mathrm{aA}$ & $7.6 \mathrm{aA}$ & $8.1 \mathrm{aA}$ & $9.6 \mathrm{aA}$ & $8.5 \mathrm{a}$ \\
\hline \multicolumn{6}{|l|}{$\mathrm{MSD}=2.14$} \\
\hline Means of factors & $8.2 \mathrm{a}$ & $7.9 \mathrm{a}$ & $8.8 \mathrm{a}$ & $7.5 \mathrm{a}$ & \\
\hline \multicolumn{6}{|c|}{ Root green mass (g) } \\
\hline C-10 & $1.62 \mathrm{bA}$ & $1.09 \mathrm{bB}$ & $1.19 \mathrm{bAB}$ & $0.83 \mathrm{aB}$ & $1.18 \mathrm{~B}$ \\
\hline $\mathrm{C}-20$ & $2.87 \mathrm{aA}$ & $2.49 \mathrm{aAB}$ & $2.13 \mathrm{aB}$ & $0.71 \mathrm{aC}$ & $2.05 \mathrm{~A}$ \\
\hline \multicolumn{6}{|l|}{$\mathrm{MSD}=0.34$} \\
\hline $\mathrm{A} 1$ & $2.15 \mathrm{abA}$ & $1.77 \mathrm{bAB}$ & $1.36 \mathrm{bBC}$ & $0.84 a b C$ & $1.53 \mathrm{~b}$ \\
\hline A2 & $2.60 \mathrm{aA}$ & $2.40 \mathrm{aA}$ & $2.13 \mathrm{aA}$ & $0.41 \mathrm{bB}$ & $1.88 \mathrm{a}$ \\
\hline A3 & $1.98 \mathrm{bA}$ & $1.20 \mathrm{cAB}$ & $1.49 \mathrm{bB}$ & $1.06 \mathrm{aB}$ & $1.43 \mathrm{~b}$ \\
\hline \multicolumn{6}{|l|}{$\mathrm{MSD}=0.51$} \\
\hline Means of factors & $2.24 \mathrm{a}$ & $1.79 \mathrm{~b}$ & $1.66 \mathrm{~b}$ & $0.77 \mathrm{c}$ & \\
\hline \multicolumn{6}{|c|}{ Root dry matter (g) } \\
\hline$C-10$ & $0.27 \mathrm{bA}$ & $0.13 \mathrm{bB}$ & $0.16 \mathrm{bAB}$ & $0.09 \mathrm{bB}$ & $0.16 \mathrm{~B}$ \\
\hline$C-20$ & $0.58 \mathrm{aA}$ & $0.38 \mathrm{aB}$ & $0.38 \mathrm{aB}$ & $0.10 \mathrm{aC}$ & $0.37 \mathrm{~A}$ \\
\hline \multicolumn{6}{|l|}{$\mathrm{MSD}=0.09$} \\
\hline $\mathrm{A} 1$ & $0.48 \mathrm{aA}$ & $0.24 \mathrm{abB}$ & $0.19 \mathrm{bB}$ & $0.11 \mathrm{aB}$ & $0.94 \mathrm{~b}$ \\
\hline $\mathrm{A} 2$ & $0.45 \mathrm{aA}$ & $0.36 \mathrm{aA}$ & $0.36 \mathrm{aA}$ & $0.04 a B$ & $1.35 \mathrm{a}$ \\
\hline A3 & $0.35 \mathrm{aA}$ & $0.18 \mathrm{bB}$ & $0.26 \mathrm{abAB}$ & $0.13 a \mathrm{~B}$ & $1.00 \mathrm{~b}$ \\
\hline \multicolumn{6}{|l|}{$\mathrm{MSD}=0.14$} \\
\hline Means of factors & $0.43 a$ & $0.26 \mathrm{~b}$ & $0.27 \mathrm{~b}$ & $0.09 \mathrm{c}$ & \\
\hline
\end{tabular}

Means followed by the same lowercase letters in columns and uppercase letters in rows, if different, differ by Tukey test at $5 \%$ probability. C-10: $10 \mathrm{~cm}$ stem cuttings in $70 \mathrm{~mL}$ containers; C-20: $20 \mathrm{~cm}$ stem cuttings in 120 $\mathrm{mL}$ containers; A1: addition of $84 \mathrm{~g}$ of Osmocote ${ }^{\circledR}$ for each kilo of substrate; A2: fertigation with $84 \mathrm{~g}$ of 1414-14 N-P-K formulation for each kilo of substrate; A3: without fertilization.

Okamoto et al. (2013) evaluated different cutting lengths and substrates for the production of mulberry seedlings and highlighted that length is not the only factor that affects the success of seedling production, emphasizing that the genetic potential of cultivars is also important. Thus, such observations justify the better behavior of the cultivar IZ40 in the factors evaluated in this study. 
Porto and Bosqueti (2017) also pointed out other factors that must be taken into account when establishing mulberry plants, such as the time between harvesting the branches and planting the cuttings and the way by which this material is stored. In some cases, mulberry branches, after being cut, are kept for days stored, usually improperly. In these cases, the branches lose nutritional reserves and mainly water, thus reducing vegetative capacity over time.

Also according to the authors, the immersion of the base of cuttings in water for a time before planting provides a significant improvement in the percentage of rooting. The practice of immersion in water can be applied to whole branches or cuttings already prepared for planting. Immersion should be carried out as soon as possible after cutting. In this research, all branches underwent the same preparation process up to planting, therefore this coefficient did not interfere with the results obtained in the experiment.

Vignolo et al. (2014) reported that, in vegetative propagation, rooting success depends on several factors. Among the factors that affect the formation of roots, the presence of leaves is a positive factor of this event, corroborating the event described by Dias et al. (2012).

Auxin affect cutting rooting, although auxin is not the only substance involved. In stem cuttings, the natural auxin produced in leaves and buds moves acropetally towards the bottom of the plant, increasing its concentration at the base of the cut, along with sugars and other nutritious substances.

Root formation apparently depends on an optimal level of auxin in relation to these substances (Pereira et al., 2017). In this regard, the values found in this study for root length and production of green and dry mass did not suffer interference from the variation of production of natural auxin, since all units of cuttings, regardless of the size, were collected with two equivalent-sized leaves.

The forms of fertilization did not differ statistically regarding root length in most of the studied cultivars. However, following the observations found for shoots, the application of the readily soluble formulation provided a greater green and dry mass for the varieties IZ10/1 and Korin.

Finally, to determine the best form of fertilization for mulberry cultivars, it is necessary to take into account some factors such as the nutritional needs of the plant and the behavior of the source of N-P-K used.

According to Huett (1997), one of the benefits of using slow-release fertilizers compared to soluble fertilizers is the low loss of nutrients by leaching. Thus, Quiqui et al. (2008) concluded that the use of sources with slowrelease of nutrients in eucalyptus seedlings allows a greater production of dry matter and a greater accumulation of nutrients in shoots compared to sources with rapid-release of nutrients when using formulations with equal $\mathrm{N}$ $\mathrm{P}-\mathrm{K}$ contents. On the other hand, considering the great demand for nitrogen presented by varieties of mulberry, as Fonseca et al. (1973) reported, further studies involving the form of fertilization with N-P-K for the production of mulberry seedlings are needed.

\section{Conclusion}

The results show that for the best formation of mulberry seedlings, cuttings of $20 \mathrm{~cm}$ in length and conducted in tubes of $120 \mathrm{~mL}$ are recommended.

The treatments with Osmocote ${ }^{\circledR}$ provide a good development of mulberry seedlings but are inferior to treatments with readily soluble $\mathrm{N}$ $\mathrm{P}-\mathrm{K}$ formulation (14-14-14) in relation to most characteristics analyzed for the cultivars IZ10/1 and Korin.

The cultivars show different rooting potentials and shoot development. The best results are for Korin and IZ10/1.

\section{References}

ALMEIDA, U. O. DE, ANDRADE NETO, R. DE C., DE ARAUJO, J. M., COSTA, D. A. DA; TEIXEIRA JÚNIOR, D. L. Fertilizantes de liberação lenta na produção de mudas frutíferas. South American Journal of Basic Education, Technical and Technological, v. 6, n. 1, 2019.

BARBIZAN, E. L.; LANA, R. M. Q.; MENDONÇA, F. C.; MELO, B.; SANTOS, C. M.; MENDES, A. F. Produção de mudas de cafeeiro em tubetes associada a diferentes formas de aplicação de fertilizantes. Ciência e Agrotecnologia, edição especial, p. 1471-1480, 2002. Disponível em: https://agrogeoambiental.ifsuldeminas.edu.br/in dex.php/Agrogeoambiental/article/view/1100. Acesso em: 10 jun. 2020. 
BOMFIM, A. A. et al. Avaliação morfológica de mudas de madeira-nova (Pterogyne nitens Tull.) produzidas em tubetes e sacos plásticos e seu desempenho no campo. Floresta, Curitiba, v. 39, n. 1, p. 33-40, 2009.

https://doi.org/10.5380/rf.v39i1.13723

BRANDÃO, R. P.; NASSER, M. D.; SILVA, L. S.; OLIVEIRA, L. J.; LUNDGREN, G. A. Estaquia de clones de aceroleira em substrato comercial e areia. Colloquium Agrariae, v. 16, n. 1, p. 43-47, 2020.

https://doi.org/10.5747/ca.2020.v16.n1.a346

BRUGNARA, E. C. Produção, época de colheita e qualidade de cinco variedades de amoreira-preta em Chapecó, SC. Archives of Health Investigation, v. 7, n. 10, p. 450-454, 2018. https://doi.org/10.22491/RAC

CAMPINHOS JUNIOR, E.; IKEMORI, Y. K.; MARTINS, F. C. G. Determinação do meio de crescimento mais adequado à formação de mudas de Eucaliptus sp. e Pinus sp. em recipientes plásticos rígidos. In: SIMPÓSIO INTERNACIONAL: MÉTODOS DE PRODUÇÃO E CONTROLE DE QUALIDADE DE SEMENTES E MUDAS FLORESTAIS, 1984, Curitiba. Anais [...]. Curitiba: UFPR, 1984. p. 350-365.

DIAS, J. P. T.; TAKAHASHI, K.; DUARTE FILHO, J.; ONO, E.; ORIKA, E. Bioestimulante na promoção da brotação em estacas de raiz de amoreirapreta. Revista Brasileira de Fruticultura, v. 34, n. 1, p. 1-7, 2012. https://doi.org/10.1590/S0100$\underline{29452012000100003}$

FONSECA, A. S.; DECHEN, A. R.; HAAG, H. P. Nutrição mineral da amoreira, Morus alba L., deficiências dos macronutrientes e boro em três variedades de amoreira. Boletim de Indústria Animal, v. 30, n. 2, p. 369-374, 1973. Disponível em:

https://www.scielo.br/pdf/aesalq/v30/12.pdf. Acesso em: 14 jun. 2020.

GONÇALVES, J. L. M.; BENEDETTI, V. Nutrição e fertilização florestal. São Paulo: IPEF, 2005. 427 p.

GUIMARÃES, P. T. G.; ANDRADE NETO, A.; BELLINI JUNIOR, O.; ADÃO, W. A.; SILVA, E. M. A produção de mudas de cafeeiros em tubetes. Informe Agropecuário, v. 19, n. 193, p. 98-109, 1998.
Disponível

em: https://scielo.conicyt.cl/scielo.342920090003006 007. Acesso em: 25 maio 2020.

HAIDA, K. S.; SILVA, F. J. da; COLEHO, R. S. M.; LIMA, D. S. de; ABRÃO, R. M.; HAIDA, K. Y. Caracterização físico-química e atividade antioxidante de amoreira-preta (Morus nigra L.). Revista Brasileira de Ciências da Saúde, v. 12, n. 40, abr/jun, 2014.

https://doi.org/10.13037/rbcs.vol12n40.2185

HAWERROTH, F. J.; SERRANO, L. A. L.; MARTINS, M. V. V.; OLIVEIRA, M. M. T. Doses de adubo de liberação lenta na produção de mudas de pinheira em tubetes. Fortaleza: Embrapa Agroindústria Tropical, 2013. (Boletim de pesquisa e desenvolvimento, 79). $21 \mathrm{p}$.

HUETT, O. O. Fertiliser use efficiency by containerised nursery plants. 2. nutrient leaching. Australian Journal of Agricultural Research, v. 48, p. 251-258, 1997. https://doi.org/10.1071/A96030

LANDIS, T. D.; TINUS, R. W.; MCDONALD, S. E.; BARNETT, J. P. Seedling nutrition and irrigation. In: USDA. The container tree nursery manual. $v$. 4, 1989. 119 p. (Agriculture Handbook, 674).

LIMA FILHO, P., LELES, P. S. dos S., ABREU, A. H. $M$ de, SILVA, E. V. da, FONSECA, A. C. da. Produção de mudas de Ceiba speciosa em diferentes volumes de tubetes utilizando o biossólido como substrato. Ciênc. Florest, Santa Maria, v. 29, n. 1, p. 27-39, mar. 2019. https://doi.org/10.5902/1980509819340

LIMA, J. E. O. Novas técnicas de produção de mudas cítricas. Laranja, v. 2 , n. 7, p. 463-468, $1986 . \quad$ Disponível em: https://www.scielo.br/scielo.php.847820010004 0002800027 . Acesso em: 16 maio 2020.

MOREIRA, R. A.; RAMOS, J. D.; CRUZ, M. C. M.; VILLAR, L.; HAFLE, O. M. Efeito de doses de polímero hidroabsorvente no enraizamento de estacas de amoreira. Revista Agrarian, v. 3, n. 8, p. 133-139, 2010. Disponível em: http://ojs.ufgd.edu.br/index.php/agrarian/article /view/913. Acesso em: 10 jun. 2020.

OKAMOTO, F.; VIDAL, A. A.; FUNAI, C. H.; MARTINS, A. N.; FURLANETO, F. P. B.; GAZOLA, E. 
Diferentes comprimentos de estaca e substratos na produção de mudas de amoreira (Morus spp.). Revista Brasileira de Ciências Agrárias, v. 8, n. 2, p. 218-222, 2013.

\section{https://doi.org/10.5039/agraria.v8i2a2415}

OKAMOTO, F.; PORTO, A. J.; SOUZA, A. L. P. Efeito dos tratamentos pré-plantio no pegamento de estacas de cultivares de amoreira (Morus spp.). Boletim de Indústria Animal, v. 62, n. 4, p. 281288, 2005.

PADILHA, M. M.; MOREIRA, L. Q.; MORAIS, F. F.; ARAÚJO, T. H.; ALVES, G. S. Estudo farmacobotânico das folhas de amoreira-preta, Morus nigra L. Revista Brasileira de Farmacognosia, v. 20, n. 4, p. 621-626, 2010.

https://doi.org/10.1590/s0102-

695X2010000400024

PEREIRA, L. C.; MENONCINI, H.; ABREU, F. F.; JADOSKI, C. J.; GUILHERME, D. O. Influência da auxina e substratos no desenvolvimento de brotos de estacas de amora. In: CONGRESSO TÉCNICO CIENTÍFICO DA ENGENHARIA E DA AGRONOMIA, 4., 2017, Belém. Anais [...] Belém: CONFEA, 2017. 5 p.

PORTO, A. J.; BOSQUETI, B. B. Uso da água no enraizamento de estacas de amoreira. Pesquisa \& Tecnologia, v. 14, n. 2, p. 1-6, 2017. Disponível em:

https://pt.slideshare.net/ruralpecuariapecuaria/u so-da-gua-no-enraizamento-de-estacas-de-

amoreira. Acesso em: 08 jun. 2020.

QUIQUI, E. M. D.; MARTINS, S. S.; PINTRO, J. C.; ANDRADE, P. J. P.; MUNIZ, A. S. Crescimento e composição mineral de mudas de eucalipto cultivadas sob condições de diferentes fontes de fertilizantes. Acta Scientiarum Agronomy, v. 26, n. 3, p. 293-299, 2008.

https://doi.org/10.4025/actasciagron.v26i3.1826

TAKAHASHI, R.; TAKAHASHI, K. M.; TAKAHASHI, L. S. Sericicultura: uma promissora exploração agropecuária. Jaboticabal: Funep, 2009. 100 p.

TEIXEIRA, C. P.; HAFLE, O. M.; MOREIRA, R A. CRUZ, M. C. M.; SANTOS, V. A.; COSTA, A. C. Tipos de estacas e substratos na produção de mudas de amoreira (Morus rubra). In: CONGRESSO BRASILEIRO DE FRUTICULTURA, 20., 2008, Vitória. Anais [...]. Vitória: SBF, 2008. CD rom.
TEIXEIRA, P. C.; RODRIGUES, H. S.; LIMA, W. A. A.; ROCHA, R. N. C.; CUNHA, R. N. V.; LOPES, R. Influência da disposição dos tubetes e da aplicação de fertilizantes de liberação lenta, durante o pré-viveiro, no crescimento de mudas de dendezeiro (Elaeis guineensis Jacq.). Ciência Florestal, v. 19, n. 2, p. 157-168, 2009.

https://doi.org/10.5902/19805098407

TINOCO, S. T. J.; PORTO, A. J.; ALMEIDA, A. M.; SOUZA, C. G.; OKAMOTO, F.; OKAWA, H.; ALMEIDA, J. E.; TAKAHASHI, J. N.; MARGATHO, L. F. F.; NAKATA, N.; TAKAHASHI, R.; FONSECA, T. C.; UCHINO, T.; HIGASHIKAWA, T.; SILVA, W. H. Manual de sericicultura. Campinas: CATI, 2000. 71 p. (Manual Técnico, 75).

VALE, D. W. DO; PRADO, R. DE M.; GONDIM, A. R. O.; TAKAHASHI, R.; RIBEIRO, M. A. Curva de crescimento e marcha de absorção de macronutrientes em três cultivares de amoreira (Morus alba L). R.C. Suelo Nutr. Veg., Temuco, v. 9, n. 1, p. 1-13, 2009.

https://doi.org/10.4067/S0718-

27912009000100001

VICHIATO, M. Influenciada fertilização do porta enxerto tangerina (Citrus reslini) em tubetes, até a repicagem. 1996. 82 f. Dissertação (Mestrado em Fitotecnia) - Universidade Federal de Lavras, 1996.

VIGNOLO, G. K.; PICOLOTTO, L.; GONÇALVES, M. A.; PEREIRA, I. S.; ANTUNES, L. E. C. Presença de folhas no enraizamento de estacas de amoreirapreta. Ciência Rural, v. 44, n. 3, p. 467-472, 2014. https://doi.org/10.1590/S010384782014000300013

VILLA, F.; PIO, R.; CHALFUN, N. N. J.; GONTIJO, T. C. A.; DUTRA, L. F. Propagação de amoreira-preta utilizando estacas lenhosas. Ciência e Agrotecnologia, v. 27, n. 4, p. 829-834, 2003. https://doi.org/10.1590/S1413$\underline{70542003000400013}$

YAMAMOTO, L. Y.; KOYAMA, R.; BORGES, W. F. S.; ANTUNES, L. E. C.; ASSIS, A. M.; ROBERTO, S. R. Substratos no enraizamento de estacas herbáceas de amora-preta Xavante. Ciência Rural, v. 43, n. 1, p. 15-20, 2013. https://doi.org/10.1590/S0103$\underline{84782012005000135}$ 
YAMANISHI, O. K.; FAGUNDES, G. R.; MACHADO FILHO, J. A.; VALONE, G. V. Efeito de diferentes substratos e duas formas de adubação na produção de mudas de mamoeiro. Revista Brasileira Fruticultura, v. 26, n. 2, p. 276-279, $2004 . \quad$ https://doi.org/10.1590/S010029452004000200023

ZENI, A. L. B.; MOREIRA, T. D.; DALMAGRO, A. P.; CAMARGO, A.; BINI, L. A.; SIMIONATTO E. L. Evaluation of phenolic compounds and lipidlowering effect of Morus nigra leaves extract. Academia Brasileira de Ciências, v. 89, n. 4, p. 2805-2815, 2017. https://doi.org/10.1590/0001$\underline{3765201720160660}$ 